\title{
Enforcing L2 Learner Autonomy in Higher Education: The Top 50 Cited Articles
}

\author{
Lilia Raitskaya ${ }^{1}$, Natalia Mekeko ${ }^{2}$, Elena Golubovskaya ${ }^{2}$ \\ ${ }^{1}$ Moscow State Institute of International Relations (MGIMO University) \\ ${ }^{2}$ Peoples' Friendship University of Russia \\ Correspondence concerning this article should be addressed to Lilia Raitskaya, MGIMO University, 76 Pr. \\ Vernadskogo, Moscow, Russia, 119454.E-mail: raitskaya.1.k@inno.mgimo.ru

\begin{abstract}
Learner autonomy as both a pre-condition of self-efficacy and higher achievements in learning and an essential learning outcome has been in the highlight in the higher education domain for many years. This review aims to single out the most influential publications (with 10 citations or more) on foreign language and L2 learner autonomy in tertiary education in the highly reputed journals indexed with the Scopus database, with the publication period limited to the last ten years (2011-2020). The key findings show that the top 50 cited articles on learner autonomy broadly cover conceptual development; self-efficacy and motivation within the learner autonomy concept; educational technologies and web-based activities in fostering learner autonomy; country-specific issues of learner autonomy as the prevailing directions of study in the field of learner autonomy.
\end{abstract}

Keywords: learner autonomy, higher education, L2, language learning, self-efficacy, motivation, self-regulated learning

\section{Introduction}

\section{Learner Autonomy in Learning Languages}

In the recent years, several concepts have become or developed into the backbone constructs in higher education. In the 1980s-1990s, learner autonomy came into the limelight. Then it led to greater focus on selfregulation, self-efficacy, learning strategies, learner-centered education, and self-regulated learning. Every five or ten years the mainstream research takes a bend or faces new challenges.

In modern higher education, knowledge building has shifted from "the ready-made knowledge" transferred by the teacher to the knowledge acquisition by the learner on their own. Learning follows the needs of the societies that are transforming (Reigeluth \& Joseph, 2002). The superfluous information settings with shorter life cycles for the new knowledge demand that the learner manage to build it independently. "Education has laid great stress on individual acquiring knowledge" (Lin \& Reigeluth, 2019). Thus, the learner autonomy concept has turned into the essential outcome of higher education. National curricula in many countries even identify learner autonomy as one of the key learning outcomes ( $\mathrm{Pu}, 2020)$. Education at large aims to support students in thriving in the digital age and providing them with a more individualised and customised learning experience (Ozer \& Yukselir, 2021).

When it comes to foreign language learning, learner autonomy is still among the top themes for researchers and academics. The concept of learner autonomy (LA) was first defined in 1981 by Henri Holec. Though he coined the name of the concept in his book "Autonomy and Foreign Language Learning" (Holec, 1981), its gist and importance were previously discussed by the EU institutions in their major projects in modern languages in the period between 1964 and 1974 as language learning was considered a crucial factor in the successful promotion of European integration. 


\section{Table 1}

Learner Autonomy and Autonomous Learner Definitions and Attributes

\begin{tabular}{lll}
\hline \multicolumn{1}{c}{ Year } & \multicolumn{1}{c}{ Researcher(s) } & \multicolumn{1}{c}{ Definition or Attributes } \\
\hline 1981 & Holec, H. & the ability to take charge of one’s own learning (Holec, 1981) \\
1991 & Candy, P.C. & $\begin{array}{l}\text { knowledge is ... built by the learner (Candy, 1991) } \\
\text { fully autonomous learning exists only as an ideal concept; most beginner EFL learners are not } \\
\text { autonomous } \\
\text { (Nunan, 1997) }\end{array}$ \\
& Nunan, D. & LA involves critical reflection, decision-making and independent action (Little, 2007, p.30) \\
2007 & Little, D. & $\begin{array}{l}\text { a testable construct in foreign language education contexts" (Benson, 2010, p.95) } \\
\text { a “fully autonomous language learner can manage their learning in the absence of the classroom, } \\
\text { teacher, or textbooks"; "LA is not synonymous with learning without teachers" (Khaerudin \& } \\
\text { Chik, 2021, p.39) }\end{array}$ \\
\hline
\end{tabular}

\section{Self-Regulated Learning and Other Concepts}

Self-regulation occupies an important niche in education. This construct, affecting academic achievements at all levels of education, was consequently translated into self-regulated learning. Boekaerts, Maes \& Karoly (2005) describe self-regulation as multi-component, iterative, self-steering processes in the service of one's own goals. The salient trait of self-regulated learning is attributed to self-control. Adaptive strategies of learners who are engaged into this kind of learning are multiple and include cognitive, meta-cognitive, motivation and other strategies.

In their systematic review of self-regulated learning strategies, Broadbent \& Poon's combined taxonomy encompasses metacognition, time management, effort regulation, peer learning, elaboration, rehearsal, organization, critical thinking (Broadbent \& Poon, 2015).

Boekarts \& Cascallar outline that the students involved in this learning should be "aware of the motivation, volition, and coping strategies" (Boekarts \& Cascallar, 2006, p. 201). Zimmerman (1990) describes self-regulated learners as approaching "tasks with confidence, diligence, and resourcefulness" (Zimmerman, 1990, p. 4). They assume greater responsibility for their educational outcomes.

All learners are self-regulated to a degree. But to distinguish self-regulated learners, Zimmerman also features their awareness of relations between regulatory process and learning outcomes and their use of strategies in learning (Zimmerman, 1990).

Self-regulated learning and closely related concepts of self-directed learning and independent learning, all in all, do with fostering learner autonomy. The basic difference lies in the focus of the activities. With selfregulation as the psychological backbone of autonomy, self-directed learning and independent learning have become paths for learners to greater autonomy and educational achievements.

In considering the self-regulation structure, researchers map various subprocesses, including motivation and self-efficacy along with task analysis, self-control, self-observation, self-evaluation and others. In studying learner autonomy, those processes and features are also tackled. On its own, motivation forms an educational field of study, helping to facilitate self-acquisition of knowledge.

To map the most essential themes and directions of research on language learner autonomy, we are to answer the following research questions:

1. What are the trend-setters in the field of language learner autonomy?

2. How influential are the relevant concepts (motivation; self-efficacy; self-regulated learning) in the topcited research on language learner autonomy? 


\section{Methodology}

\section{Search Strategy}

As the Scopus database encompasses the most reputed peer-reviewed journals in the education domain, the search strategy was focussed primarily on the sources indexed there. The initial search was conducted for all the documents relating to "learner autonomy". Then, the search results were refined and limited to the criteria of years (2016-2021); subject area (Social Sciences): document type (article, review), and keywords (higher education; independent learning; teacher autonomy; self-efficacy; foreign language learning; self-regulated learning; autonomous learner).

The period covers ten years that is wide enough to detect the new directions and shifts in the learner autonomy research.

As educational research is part of Social Sciences, the latter were singled out as the primary inclusion criterion. Many peer-reviewed journals focus on several closely related areas. Thus, their publications may be considered as attributed to more than one subject area. Anyway, it presumably agrees with the chosen subject area criterion.

Then, all the results were listed based on their citation scores (from the highest to the lowest).

Based on our questionnaire conducted among 20 experts (educators; academics; researchers) from three Russian universities (MGIMO University; RUDN University; Moscow State University of Food Production), we singled out the following extra keywords relevant to the learner autonomy phenomenon: higher education; independent learning; teacher autonomy; self-efficacy; foreign language learning; self-regulated learning; autonomous learner.

\section{Questionnaire on Learner Autonomy in Higher Education}

To reach more objectivity in selecting the literature for our review on learner autonomy, we turned to twenty experts in the domain with a short questionnaire.

The participants included five university professors of linguistics, and education; five researchers; ten faculty members and lecturers of foreign languages.

The questionnaire encompassed the following questions:

Question 1. Enumerate up to five keywords relevant to learner autonomy in higher education.

Question 2. What are the most essential concepts closely connected with learner autonomy?

Based on Question 1, the prevailing answers formed the extra keyword pool that we used in limiting our search (See Table 2).

As for Question 2, the most popular answers included self-efficacy (11 participants); motivation (10 participants); self-regulated learning (8 participants); teacher autonomy (7 participants); web-based learning (4 participants); self-directed learning (4 participants); independent learning (4 participants); computerassisted learning - CALL (3 participants); mobile learning (2 participants); computer-mediated learning (1 participant). These concepts were partially covered in the introduction to the review to show the interrelations within the field. 


\section{Inclusion and Exclusion Criteria}

\section{Table 2}

Inclusion and Exclusion Criteria

\begin{tabular}{|c|c|c|}
\hline Criterion Aspect & Inclusion Criteria & Exclusion Criteria \\
\hline Period & $2011-2021^{1}$ & Before $2011 ; 2022$ (in press publications 2022) \\
\hline Subject Areas & Social Sciences & $\begin{array}{l}\text { Other Areas if the publications are not } \\
\text { simultaneously attributed to Social Sciences }\end{array}$ \\
\hline Types of Publications & $\begin{array}{l}\text { Article } \\
\text { Review }\end{array}$ & All publications beyond the inclusion criterion \\
\hline Keywords & $\begin{array}{l}\text { Learner autonomy (the initial keyword for } \\
\text { the search) } \\
\text { Extra keywords: } \\
\text { higher education; } \\
\text { independent learning; } \\
\text { teacher autonomy; } \\
\text { self-efficacy; } \\
\text { foreign language learning; } \\
\text { self-regulated learning; } \\
\text { autonomous learner }\end{array}$ & All publications beyond the inclusion criterion \\
\hline Citations of the documents & 10 and more citations & Fewer than 10 citations \\
\hline Level of education & Higher (tertiary) education & $\begin{array}{l}\text { Elementary education; secondary education; } \\
\text { corporate and business education; further } \\
\text { education; additional education }\end{array}$ \\
\hline Disciplines & Foreign language/ L2 & All other disciplines \\
\hline
\end{tabular}

\section{Scope of the Review}

The review was limited to 50 publications, with the citation scores starting with 10 . When we got down to our review, we agreed that we would include only the publications with citations of 10 and higher. Influential publications in different subject areas may score various numbers of citations. For Social Sciences (Education) as well as Arts \& Humanities (Language and Linguistics) reviews tend to single out documents starting approximately with 10 citations.

\section{Supporting Publications}

To support the understanding and give a broader conceptual view of the topical clusters based on the autonomyrelated concepts, we selected the documents, relevant to LA and the concepts outlined in the questionnaire from the top journals (mainly highly cited Scopus-indexed articles and reviews). The time span for the extra sources was not limited as some of them were published when the concept of learner autonomy was worded (1981) or a little later.

Though having served as a theoretical basis for the review, the associated extra sources did not enter the Top 50 Most Cited Publications.

\section{Procedure}

The initial search with "learner autonomy" in the category covering document titles, abstracts, and keywords brought 1,131 results, including 869 documents indexed between 2016 and 2021 . Out of 869 results, 589 publications were attributed to Social Sciences. Limitation to the extra keywords boiled down the results to 335 .

\footnotetext{
1 The 2021 data are incomplete. But the review does not include any publications for 2021, as so far they have been cited fewer than 10 times.
} 
The results were sorted on the citation (from the highest to the lowest). The highest citation score hit 345 . Then, each author was to select the 50 top cited results in compliance with the inclusion criteria. There were only a few (three) documents which caused doubt. General nature of research was combined with some miscompliance with the inclusion criteria (e.g. McMillan, \& Rivers, 2011). Having discussed the final list, we singled out 50 articles and reviews (See Appendix 1) out of the first 65 selected documents.

While filtering the search results through the inclusion criteria, upon mutual agreement, we excluded 15 documents being beyond compliance. The excluded publications are given in Table 3 below with our reasoning for their elimination explained.

\section{Table 3}

\section{The Excluded Documents: Rationales}

\begin{tabular}{cl}
\hline Nos & \multicolumn{1}{c}{ Document } \\
\hline 1 & $\begin{array}{l}\text { Al Nashash, H., \& Gunn, C. (2013). Lecture capture in engineering } \\
\text { classes: Bridging gaps and enhancing learning. }\end{array}$ \\
2 & $\begin{array}{l}\text { Burner, T. (2014). The potential formative benefits of portfolio } \\
\text { assessment in second and foreign language writing contexts: A review } \\
\text { of the literature. }\end{array}$ \\
3 & $\begin{array}{l}\text { Chik, A., \& Ho, J. (2017). Learn a language for free: Recreational } \\
\text { learning among adults. }\end{array}$ \\
4 & $\begin{array}{l}\text { Hornstra, L., Mansfield, C., van der Veen, I., Peetsma, T., \& Volman, } \\
\text { M. (2015). Motivational teacher strategies: The role of beliefs and } \\
\text { contextual factors. }\end{array}$ \\
5 & $\begin{array}{l}\text { Kuchah, K., \& Smith, R. (2011). Pedagogy of autonomy for difficult } \\
\text { circumstances: From practice to principles. Innovation in Language } \\
\text { Learning and Teaching, 5(2), 119-140. doi:10.1080/17501229.2011.577 } \\
\text { 529 }\end{array}$
\end{tabular}

6 Lengkanawati, N. S. (2017). Learner autonomy in the Indonesian EFL settings.

7 Liakin, D., Cardoso, W., \& Liakina, N. (2015). Learning L2 pronunciation with a mobile speech recognizer: French/y/. CALICO Journal, 32(1), 1-25. doi:10.1558/cj.v32i1.25962

8 Nielsen, P. L., Bean, N. W., \& Larsen, R. A. A. (2018). The impact of a flipped classroom model of learning on a large undergraduate statistics class.

9 Rose, H., \& Harbon, L. (2013). Self-regulation in second language learning: An investigation of the kanji-learning task.

10 Scott, G. W., Furnell, J., Murphy, C. M., \& Goulder, R. (2015). Teacher and student perceptions of the development of learner autonomy; a case study in the biological sciences.

11 Sockett, G., \& Toffoli, D. (2012). Beyond learner autonomy: A dynamic systems view of the informal learning of English in virtual online communities.

12 Ting, Y. (2015). Tapping into students' digital literacy and designing negotiated learning to promote learner autonomy.

13 Tsuda, A., \& Nakata, Y. (2013). Exploring self-regulation in language learning: A study of Japanese high school EFL students.

14 Yasmin, M., Sarkar, M., \& Sohail, A. (2016). Exploring English language needs in the hotel industry in Pakistan: An evaluation of existing teaching material.

15 Yeh, Y., \& Lan, Y. (2018). Fostering student autonomy in English learning through creations in a 3D virtual world.

Rationale

The article does not relate to foreign language learning. Learner autonomy is considered in capturing lectures in engineering.

Portfolio assessment in secondary education.

Recreational learning among adults. Informal education.

Motivation in language learning in secondary school.

Learner autonomy in secondary school setting.

Learner autonomy in secondary school setting.

Mobile-assisted foreign language learning in elementary school.

Flipped classroom in statistics class at university.

Language learner autonomy in secondary school (kanji-learning task; kanji, the name for Japanese written characters).

Learner autonomy in the biological sciences.

Web-based informal foreign language learning of adults in their spare time.

Web-based activities in secondary school.

Self-regulation in language learning in secondary school.

Language learning in the workplace.

Self-assessment of learner autonomy in English language learning in secondary school. 
The top 50 most cited documents were broken down into thematic clusters. Each author labelled the documents, then, the breakdowns were checked for consistency. On the whole, no contradictions in the rationales were found.

Before the content analysis, the following six clusters were hypothesized: learner autonomy: theory and conceptualization; self-efficacy and motivation in the LA concept; self-regulated learning; educational technologies and LA; web-based activities in fostering LA; country-specific issues of LA development.

\section{Results and Discussion}

The top 50 publications range from the highest 345 citations (Kop, 2011) to the lowest of 12 citations (Gardner \& Miller, 2011; Lenkaitis, 2020; Phan \& Hamid, 2017).

The analysis of the review results showed that there is a slight trend toward fewer highly cited publications on LA, with 14 publications in 2011; 6 in 2012; 9 in 2013; 3 in 2014 and 2015 each; 5 in 2016; 3 in 2017; 4 in 2018;2 in 2019; 1 in 2020. If the lower numbers for the recent 3-5 years can be caused by the insufficient time for citation, the previous years might have other reasoning.

The review publications were distributed among 27 journals, with the leading position and 11 publications in the Language Learning and Technology; 6 publications in the Computer Assisted Language Learning; 3 publications in the System. Another six journals published by two articles; 18 journals had one publication each.

Geographically, the leading affiliations belonged to the USA (10 publications); Australia (6 publications); Japan (6 publications); Hong Kong (5 publications); the UK (5 publications). The top affiliations included the University of Hong Kong (3); City University of Hong Kong (3); National Research Council Canada (2); University System of New Hampshire (2); and the University of Queensland (2).

By the type of publication (the review was limited to articles and reviews), there were 47 articles, and 3 reviews.

All the documents on the top 50 list belonged to the Social Sciences Domain. But at the same time, some of them were also marked as Arts \& Humanities (37 documents); Computer Science (23 documents); and Business, Management and Accounting (1 document).

Four researchers (Kop, R.; Lee, L.; Miller, L.; Rivers, D.J.) authored two publications each. The remaining 73 authors participated in one publication. On average, each publication had 1.54 authors.

\section{Thematic Clusters}

The thematic clusters essentially proved the above hypothesis and totalled five. We failed to find stand-alone publications on self-regulated learning in the search for "LA". The ultimate clusters were as follows: learner autonomy: theory and conceptualization; self-efficacy and motivation within the LA concept; educational technologies and LA; web-based activities in fostering LA; country-specific issues of LA development (See Table 4).

The top 50 cited publications were distributed among the clusters with some overlappings. Essential part of publications entered two or more clusters due to the complex nature of the research. 
Table 4

Thematic Clusters on Foreign Language Learner Autonomy

\begin{tabular}{|c|c|c|}
\hline Thematic Clusters & $\begin{array}{l}\text { Number of Publications out } \\
\text { of Top } 50\end{array}$ & Brief Cluster Description \\
\hline $\begin{array}{l}\text { Language Learner Autonomy: Theory } \\
\text { and Conceptualization }\end{array}$ & 12 & $\begin{array}{l}\text { The cluster focuses on the learner autonomy theory development } \\
\text { There are articles on perception of the phenomenon and some } \\
\text { insights into the general understanding of the field. }\end{array}$ \\
\hline $\begin{array}{l}\text { Self-Efficacy and Motivation within the } \\
\text { LA Concept }\end{array}$ & 9 & $\begin{array}{l}\text { The theoretical and empirical publications relating to the } \\
\text { concepts of self-efficacy and motivation. }\end{array}$ \\
\hline Educational Technologies and LA & 16 & $\begin{array}{l}\text { Educational technologies cover publications on MOOC; online } \\
\text { learning; task-based instruction; strategy-based instruction; } \\
\text { CALL; flipped classroom; blended learning. }\end{array}$ \\
\hline Web-Based Activities in Fostering LA & 12 & $\begin{array}{l}\text { The activities embrace collaborative writing; wikis; blogging; } \\
\text { gaming; storytelling; virtual communities; videoconferencing; } \\
\text { Web 2.0. tools, etc. }\end{array}$ \\
\hline $\begin{array}{l}\text { Country-Specific Issues of LA } \\
\text { Development }\end{array}$ & 18 & $\begin{array}{l}\text { The publications in this cluster give a glimpse of country- } \\
\text { related experiences in learner autonomy practice in the tertiary } \\
\text { education. }\end{array}$ \\
\hline
\end{tabular}

\section{Language Learner Autonomy: Theory and Conceptualization}

This cluster ranges from theoretical aspects of LA to the LA perceptions of the educational process participants (teachers and students). Fuchs, Hauck, \& Müller-Hartmann (2012) found that learner autonomy was promoted through awareness as a result of implemented models as well as multiliteracy skills development based on social networking tools. Awareness was also found the key factor in fostering teachers' autonomy. Gao, 2013 analyzed and proved a crucial link between reflexive and reflective thinking and autonomy (Gao, 2013).

LA is thoroughly analyzed in various contexts, including the technologies in current use by L2 learners (Steel \& Levy, 2013) and the technologies outside the classroom (Lai, Yeung \& Hu, 2016); the self-directed learning (Navarro \& Thornton, 2011);

Reinders \& White (2016) outlined LA as “an assumed goal of language education" throughout the world. The focused on the close relationship between Computer-Assisted Language Learning (CALL) and LA, informing each other.

We found that there were some theoretical research that gave insights into the role constructivism played in L2 learner autonomy (Wang, 2011) and self-determination theory as a theoretical rationale for learner autonomy (Hu \& Zhang, 2017).

\section{Self-Efficacy and Motivation}

Self-efficacy as an integral part of LA has taken its stake in the research on LA for years. In the review, a few highly cited articles dealt with various aspects of self-efficacy. Tilfarlioglu \& Ciftci (2011) conducted their casestudy research to determine the links between self-efficacy andLA, and find the relationship between selfefficacy and academic success.

The articles on motivation in language learning gives a glimpse of its relationships with LA (Ueki \& Takeuchi, 2013; Chartrand, 2012; Terhune, 2016).

\section{Educational Technologies}

Interrelations between autonomy and technology have been studied since the term "learner autonomy" became an integral part of the educational discourse. Reinders \& White (2016) gave an overview of 20 years of the field development. Though five years have passed ever since, many issues they outlined are still high on the agenda, 
with some new swathes of topics coming into the highlight. More to this end, Steel \& Levy (2013) charted the evolution of technologies prevailing in language learning.

One of the most highly cited sub-topics in the cluster (the first three publications on the list) deals with MOOCs, including learning experiences and challenges (Kop, 2011); issues of participant support (Kop, Fournier \& Mak, 2011); massiveness, openness, and design of MOOCs (Baggaley, 2013).

Other themes cover autonomous learning through task-based instruction (Lee, 2016); multiliteracy skills development. There were publications on LA in L2 university students' writing and automated evaluation technologies (Wang, Shang \& Briody, 2013); LA in blended learning; computer-assisted language learning (CALL); collaborative learning; Skype-based computer mediated communication; interaction in distance education; mobile assisted language learning; flipped classroom; and videoconferencing.

\section{Web-Based Activities}

Web-based activities developing LA included in this cluster feature web-based projects (Kessler, Bikowski \& Boggs, 2012); blogging (Lee, 2011); digital gaming (Chik, 2014); corpus-building and concordancing; digital storytelling (Kim, 2014); Web 2.0 tools, including social networking (Chartrand, 2012); wikis (Pellet, 2012), and some others.

\section{Country-Specific Issues}

The cluster encompasses research conducted in Hong Kong - a digital video project in English for science (Hafner \& Miller, 2011); technologies in autonomous language learning outside the classroom (Lai, Yeung, \& $\mathrm{Hu}, 2016)$; managing self-access language learning; in Vietnam - strategy-based instruction on the promotion of LA (Nguyen \& Gu, 2013); LA in foreign language policies; in Australia - the technologies in use by L2 learners (Steel \& Levy, 2013); learning support in flipped classroom (Wang \& Qi, 2018); in Thailand; in Turkey; in Japan - motivational self-system; blended learning in a CALL environment, etc.; in Saudi Arabia - perceptions of LA; the impact of mobile assisted language learning on LA; in Pakistan - socio-cultural barriers in LA (Yasmin \& Sohail, 2018); and in China.

The research in international settings (Germany, Poland, the UK, and the USA) helped to receive empirical findings relating to LA in a task-based telecollaborative learning format (Fuchs, Hauck \& Müller-Hartmann, 2012).

\section{Conclusion}

\section{Research Question One}

The review did not find any strikingly new and unexpected directions of study. The trend-setters met the hypothesis and included country-specific issues of LA development (18 publications); educational technologies and LA (16 publications); theory and conceptualization of learner autonomy (12 publications); web-based activities in fostering LA (12 publications); self-efficacy and motivation within the LA concept (9 publications).

\section{Research Question Two}

The relevant concepts of motivation; self-efficacy; and self-regulated learning are influential, but to a degree. The relationships between LA and motivation; LA and self-efficacy were studied in nine publications out of 50 . Self-regulated and self-directed learning as a stand-alone direction was not the case with only one publication in the review.

The limitations of the review are connected with the search strategy applied. Other databases might be sought to double-check the findings of the present study. More sources and publications are certain to refine or adjust the results. 


\section{Declaration of Competing Interest}

None declared.

\section{References}

Al Nashash, H., \& Gunn, C. (2013). Lecture capture in engineering classes: Bridging gaps and enhancing learning. Educational Technology and Society, 16(1), 69-78.

Baggaley, J. (2013). MOOC rampant. Distance Education, 34(3), 368-378. https://doi.org/10.1080/01587919.201 3.835768

Benson, P. (2000). Autonomy as a learners' and teachers' right. In B. Sinclair, I. Mcgrath, \& T. Lamb (Eds.), Learner autonomy, teacher autonomy: Future directions. (pp. 111-117). Addison Wesley Longman.

Benson, P. (2010). Measuring autonomy: Should we put our ability to the test? In A. Paran \& L. Sercu (Eds.), Testing the untestable in language education (pp. 120-139). Multilingual Matters.

Boekaerts, M., \& Cascallar, E. (2006). How far have we moved toward the integration of theory and practice in self-regulation?.Education Psychology Review, 18, 199-210. https://doi.org/10.1007/s10648-006-9013-4

Boekaerts, M., Maes, S., \& Karoly, P. (2005). Self-regulation across domains of applied psychology: Is there an emerging consensus? Applied Psychology: An International Review, 54(2), 149-154

Broadbent, J., \& Poon, W. L. (2015). Self-regulated learning strategies \& academic achievement in online higher education learning environments: A systematic review. Internet and Higher Education, 27, 1-13. https://doi. org/10.1016/j.iheduc.2015.04.007

Burner, T. (2014). The potential formative benefits of portfolio assessment in second and foreign language writing contexts: A review of the literature. Studies in Educational Evaluation, 43, 139-149. https://doi. org/10.1016/j.stueduc.2014.03.002

Candy, P. C. (1991). Self-direction for lifelong learning. Jossey-Bass.

Chartrand, R. (2012). Social networking for language learners: Creating meaningful output with web 2.0 tools. Knowledge Management and E-Learning, 4(1), 97-101.

Chik, A. (2014). Digital gaming and language learning: Autonomy and community. Language Learning and Technology, 18(2), 85-100.

Chik, A., \& Ho, J. (2017). Learn a language for free: Recreational learning among adults. System, 69, 162-171. https://doi.org/10.1016/j.system.2017.07.017

Fuchs, C., Hauck, M., \& Müller-Hartmann, A. (2012). Promoting learner autonomy through multiliteracy skills development in cross-institutional exchanges. Language Learning and Technology, 16 (3), 82-102.

Gao, X. (2013). Reflexive and reflective thinking: A crucial link between agency and autonomy. Innovation in Language Learning and Teaching, 7(3), 226-237. https://doi.org/10.1080/17501229.2013.836204

Gardner, D., \& Miller, L. (2011). Managing self-access language learning: Principles and practice. System, 39(1), 78-89. https://doi.org/10.1016/j.system.2011.01.010

Hafner, C. A., \& Miller, L. (2011). Fostering learner autonomy in English for science: A collaborative digital video project in a technological learning environment. Language Learning and Technology, 15(3), 68-86.

Hanaoka, O., \& Izumi, S. (2012). Noticing and uptake: Addressing pre-articulated covert problems in L2 writing. Journal of Second Language Writing, 21(4), 332-347. https://doi.org/10.1016/j.jslw.2012.09.008

Holec, H. (1981). Autonomy and foreign language learning. Pergamon Press.

Hornstra, L., Mansfield, C., van der Veen, I., Peetsma, T., \& Volman, M. (2015). Motivational teacher strategies: The role of beliefs and contextual factors. Learning Environments Research, 18(3), 363-392. https://doi. org/10.1007/s10984-015-9189-y

Hu, P., \& Zhang, J. (2017). A pathway to learner autonomy: A self-determination theory perspective. Asia Pacific Education Review, 18(1), 147-157. https://doi.org/10.1007/s12564-016-9468-z

Hurd, L. (2008). Language learning strategies in independent settings. Multilingual Matters.

Kessler, G., Bikowski, D., \& Boggs, J. (2012). Collaborative writing among second language learners in academic web-based projects. Language Learning and Technology, 16(1), 91-109.

Khaerudin, T., \& Chik, A. (2021). Evaluating supports for learner autonomy in ELT textbooks. Journal of Asia TEFL, 18(1), 39-56. https://doi.org/10.18823/asiatefl.2021.18.1.3.39

Kim, S. (2014). Developing autonomous learning for oral proficiency using digital storytelling. Language Learning and Technology, 18(2), 20-35.

Kop, R. (2011). The challenges to connectivist learning on open online networks: Learning experiences during a massive open online course. International Review of Research in Open and Distance Learning, 12(3), 19-38. 
https://doi.org/10.19173/irrodl.v12i3.882

Kop, R., Fournier, H., \& Mak, J. S. F. (2011). A pedagogy of abundance or a pedagogy to support human beings? Participant support on massive open online courses. International Review of Research in Open and Distance Learning, 12(7 SPECIAL ISSUE), 74-93. https://doi.org/10.19173/irrodl.v12i7.1041

Kuchah, K., \& Smith, R. (2011). Pedagogy of autonomy for difficult circumstances: From practice to principles. Innovation in Language Learning and Teaching, 5(2), 119-140. https://doi.org/10.1080/17501229 .2011 .577529

Lai, C., Yeung, Y., \& Hu, J. (2016). University student and teacher perceptions of teacher roles in promoting autonomous language learning with technology outside the classroom. Computer Assisted Language Learning, 29(4), 703-723. https://doi.org/10.1080/09588221.2015.1016441

Lee, L. (2011). Blogging: Promoting learner autonomy and intercultural competence through study abroad. Language Learning and Technology, 15(3), 87-109.

Lee, L. (2016). Autonomous learning through task-based instruction in fully online language courses. Language Learning and Technology, 20(2), 81-97.

Lengkanawati, N. S. (2017). Learner autonomy in the Indonesian EFL settings. Indonesian Journal of Applied Linguistics, 6(2), 222-231. https://doi.org/10.17509/ijal.v6i2.4847

Lenkaitis, C. A. (2020). Technology as a mediating tool: Videoconferencing, L2 learning, and learner autonomy. Computer Assisted Language Learning, 33(5-6), 483-509. https://doi.org/10.1080/09588221.2019 .1572018

Liakin, D., Cardoso, W., \& Liakina, N. (2015). Learning L2 pronunciation with a mobile speech recognizer: French/y/. CALICO Journal, 32(1), 1-25. https://doi.org/10.1558/cj.v32i1.25962

Lin, C., \& Reigeluth, C. M. (2019). Scaffolding learner autonomy in a wiki-supported knowledge building community and its implications for mindset change. British Journal of Educational Technology, 50(5), 26672684. https://doi.org/10.1111/bjet.12713

Little, D. (2001). Learner autonomy and the challenge of tandem language learning via the Internet. In A. Chambers \& G. Davies (Eds.), ICT and language learning: A European perspective (pp. 29-38). Swets \& Zeitlinger.

McMillan, B.A., \& Rivers, D. J.(2011). The practice of policy: Teacher attitudes toward “English only”. System, 39(2), 251-263. https://doi.org/10.1016/j.system.2011.04.011

Navarro, D., \& Thornton, K. (2011). Investigating the relationship between belief and action in self-directed language learning. System, 39(3), 290-301. https://doi.org/10.1016/j.system.2011.07.002

Nielsen, P. L., Bean, N. W., \& Larsen, R. A. A. (2018). The impact of a flipped classroom model of learning on a large undergraduate statistics class. Statistics Education Research Journal, 17(1), 121-140.

Nunan, D. (1997). Designing and adapting materials to encourage learner autonomy. In P. Benson \& P. Voller (Eds.), Autonomy and independence in language learning (pp. 192-203). Routledge.

Ozer, O., \& Yukselir, C. (2021). 'Am I aware of my roles as a learner?' the relationships of learner autonomy, self-direction and goal commitment to academic achievement among turkish EFL learners. Language Awareness. https://doi.org/10.1080/09658416.2021.1936539

Pellet, S.H. (2012). Wikis for building content knowledge in the foreign language classroom. CALICO Journal, 29(2), 224-248. doi:10.11139/cj.29.2.224-248

Phan, T. T. H., \& Hamid, M. O. (2017). Learner autonomy in foreign language policies in Vietnamese universities: An exploration of teacher agency from a sociocultural perspective. Current Issues in Language Planning, 18(1), 39-56. https://doi.org/10.1080/14664208.2016.1201231

$\mathrm{Pu}, \mathrm{S}$. (2020). Learner Autonomy in the National English Language Curricula for Chinese Universities 19782007: A Historical Analysis. Chinese Journal of Applied Linguistics, 43(1), 83-104. https://doi.org/10.1515/ CJAL-2020-0006

Reigeluth, C.M., \& Joseph, R. (2002). Beyond technology integration: The case for technology transformation. Educational Technology, 42 (4), pp. 9-13.

Reinders, H., \& White, C. (2016). 20 years of autonomy and technology: How far have we come and where to next? Language Learning and Technology, 20(2), 143-154.

Rose, H., \& Harbon, L. (2013). Self-regulation in second language learning: An investigation of the kanji-learning task. Foreign Language Annals, 46(1), 96-107. https://doi.org/10.1111/flan.12011

Şakrak-Ekin, G., \& Balçıkanlı, C. (2019). Does Autonomy Really Matter in Language Learning?Journal of Language and Education, 5(4), 98-111. https://doi.org/10.17323/jle.2019.8762

Scott, G. W., Furnell, J., Murphy, C. M., \& Goulder, R. (2015). Teacher and student perceptions of the development of learner autonomy; a case study in the biological sciences. Studies in Higher Education, 40(6), 945-956. 
https://doi.org/10.1080/03075079.2013.842216

Sockett, G., \& Toffoli, D. (2012). Beyond learner autonomy: A dynamic systems view of the informal learning of english in virtual online communities. ReCALL, 24(2), 138-151. https://doi.org/10.1017/S0958344012000031

Steel, C. H., \& Levy, M. (2013). Language students and their technologies: Charting the evolution 20062011. ReCALL, 25(3), 306-320. https://doi.org/10.1017/S0958344013000128

Terhune, N. M. (2016). Language learning going global: Linking teachers and learners via commercial skypebased CMC. Computer Assisted Language Learning, 29(6), 1071-1089. https://doi.org/10.1080/09588221.2015 .1061020

Tilfarlioglu, F. Y., \& Ciftci, F. S. (2011). Supporting self-efficacy and learner autonomy in relation to academic success in EFL classrooms (A case study). Theory and Practice in Language Studies, 1(10), 1284-1294. https:// doi.org/10.4304/tpls.1.10.1284-1294

Tsuda, A., \& Nakata, Y. (2013). Exploring self-regulation in language learning: A study of Japanese high school EFL students. Innovation in Language Learning and Teaching, 7(1), 72-88. https://doi.org/10.1080/17501229. 2012.686500

Ueki, M., \& Takeuchi, O. (2013). Forming a clearer image of the ideal L2 self: The L2 motivational self system and learner autonomy in a Japanese EFL context. Innovation in Language Learning and Teaching, 7(3), 238252. https://doi.org/10.1080/17501229.2013.836205

Wang, P. (2011). Constructivism and learner autonomy in foreign language teaching and learning: To what extent does theory inform practice? Theory and Practice in Language Studies, 1(3), 273-277. https://doi.org/10.4304/ tpls.1.3.273-277

Wang, Y. Shang, H., \& Briody, P. (2013). Exploring the impact of using automated writing evaluation in English as a foreign language university students' writing. Computer Assisted Language Learning, 26(3), 234-257. https://doi.org/10.1080/09588221.2012.655300

Wang, Y., \& Qi, G. Y. (2018). Mastery-based language learning outside class: Learning support in flipped classrooms. Language Learning and Technology, 22(2), 50-74. https://doi.org/10.125/44641

Yasmin, M., \& Sohail, A. (2018). Socio-cultural barriers in promoting learner autonomy in Pakistani universities: English teachers' beliefs. Cogent Education, 5(1), 1-12. https://doi.org/10.1080/2331186X.2018.1501888

Yasmin, M., Sarkar, M., \& Sohail, A. (2016). Exploring English language needs in the hotel industry in Pakistan: An evaluation of existing teaching material. Journal of Hospitality and Tourism Education, 28(4), 202-213. https://doi.org/10.1080/10963758.2016.1226846

Yeh, Y., \& Lan, Y.(2018). Fostering student autonomy in English learning through creations in a 3D virtual world. Educational Technology Research and Development, 66(3), 693-708. https://doi.org/10.1007/s11423017-9566-6

Zimmerman, B. J. (1990). Self-regulated learning and academic achievement: An overview. Educational Psychologist, 25(1), 3-17. https://doi.org/10.1207/s15326985ep2501_2 


\section{Appendix 1}

\section{The Top 50 Cited Articles on Learner Autonomy (2011-2020)}

Al Asmari, A. R. (2013). Practices and prospects of learner autonomy: Teachers' perceptions. English Language Teaching, 6(3), 1-11. https://doi.org/10.5539/elt.v6n3p1

Baggaley, J. (2013). MOOC rampant. Distance Education, 34(3), 368-378. https://doi.org/10.1080/01587919.201 3.835768

Banditvilai, C. (2016). Enhancing students' language skills through blended learning. Electronic Journal of e-Learning, 14(3), 220-229.

Benson, P. (2015). Commenting to learn: Evidence of language and intercultural learning in comments on YouTube videos. Language Learning and Technology, 19(3), 88-105.

Borg, S., \& Alshumaimeri, Y. (2019). Language learner autonomy in a tertiary context: Teachers' beliefs and practices. Language Teaching Research, 23(1), 9-38. https://doi.org/10.1177/1362168817725759

Charles, M. (2012). 'Proper vocabulary and juicy collocations': EAP students evaluate do-it-yourself corpusbuilding. English for Specific Purposes, 31(2), 93-102. https://doi.org/10.1016/j.esp.2011.12.003

Chartrand, R. (2012). Social networking for language learners: Creating meaningful output with web 2.0 tools. Knowledge Management and E-Learning, 4(1), 97-101. https://doi.org/10.34105/j.kmel.2012.04.009

Chik, A. (2014). Digital gaming and language learning: Autonomy and community. Language Learning and Technology, 18(2), 85-100.

Fuchs, C., Hauck, M., \& Müller-Hartmann, A. (2012). Promoting learner autonomy through multiliteracy skills development in cross-institutional exchanges. Language Learning and Technology, 16(3), 82-102. http:// dx.doi.org/10125/44301

Gao, X. (2013). Reflexive and reflective thinking: A crucial link between agency and autonomy. Innovation in Language Learning and Teaching, 7(3), 226-237. https://doi.org/10.1080/17501229.2013.836204

Gao, Z. (2011). Exploring the effects and use of a Chinese-English parallel concordancer. Computer Assisted Language Learning, 24(3), 255-275. https://doi.org/10.1080/09588221.2010.540469

Gardner, D., \& Miller, L. (2011). Managing self-access language learning: Principles and practice. System, 39(1), 78-89. https://doi.org/10.1016/j.system.2011.01.010

Hafner, C. A., \& Miller, L. (2011). Fostering learner autonomy in English for science: A collaborative digital video project in a technological learning environment. Language Learning and Technology, 15(3), 68-86. http:// dx.doi.org/10125/44263

Hanaoka, O., \& Izumi, S. (2012). Noticing and uptake: Addressing pre-articulated covert problems in L2 writing. Journal of Second Language Writing, 21(4), 332-347. https://doi.org/10.1016/j.jslw.2012.09.008

Hazaea, A. N., \& Alzubi, A. A. (2018). Impact of mobile assisted language learning on learner autonomy in EFL reading context. Journal of Language and Education, 4(2), 48-58. https://doi.org/10.17323/2411-7390-20184-2-48-58

Henri, D. C., Morrell, L. J., \& Scott, G. W. (2018). Student perceptions of their autonomy at university. Higher Education, 75(3), 507-516. https://doi.org/10.1007/s10734-017-0152-y

Hsieh, Y. C. (2017). A case study of the dynamics of scaffolding among ESL learners and online resources in collaborative learning. Computer Assisted Language Learning, 30(1-2), 115-132. https://doi.org/10.1080/095 88221.2016 .1273245

$\mathrm{Hu}$, P., \& Zhang, J. (2017). A pathway to learner autonomy: A self-determination theory perspective. Asia Pacific Education Review, 18(1), 147-157. https://doi.org/10.1007/s12564-016-9468-z

Kessler, G., Bikowski, D., \& Boggs, J. (2012). Collaborative writing among second language learners in academic web-based projects. Language Learning and Technology, 16(1), 91-109. http://dx.doi.org/10125/44276

Kim, S. (2014). Developing autonomous learning for oral proficiency using digital storytelling. Language Learning and Technology, 18(2), 20-35. http://dx.doi.org/10125/44364

Kop, R. (2011). The challenges to connectivist learning on open online networks: Learning experiences during a massive open online course. International Review of Research in Open and Distance Learning, 12(3), 19-38. https://doi.org/10.19173/irrodl.v12i3.882

Kop, R., Fournier, H., \& Mak, J. S. F. (2011). A pedagogy of abundance or a pedagogy to support human beings? Participant support on massive open online courses. International Review of Research in Open and Distance Learning, 12(7 SPECIAL ISSUE), 74-93. https://doi.org/10.19173/irrodl.v12i7.1041

Lai, C., Yeung, Y., \& Hu, J. (2016). University student and teacher perceptions of teacher roles in promoting 
autonomous language learning with technology outside the classroom. Computer Assisted Language Learning, 29(4), 703-723. https://doi.org/10.1080/09588221.2015.1016441

Lee, L. (2016). Autonomous learning through task-based instruction in fully online language courses. Language Learning and Technology, 20(2), 81-97. http://dx.doi.org/10125/44462

Lee, L. (2011). Blogging: Promoting learner autonomy and intercultural competence through study abroad. Language Learning and Technology, 15(3), 87-109. http://dx.doi.org/10125/44264

Lenkaitis, C. A. (2020). Technology as a mediating tool: Videoconferencing, L2 learning, and learner autonomy. Computer Assisted Language Learning, 33(5-6), 483-509. https://doi.org/10.1080/09588221.2019 .1572018

McMillan, B.A., \& Rivers, D. J.(2011). The practice of policy: Teacher attitudes toward “English only”. System, 39(2), 251-263. https://doi.org/10.1016/j.system.2011.04.011

Mutlu, A., \& Eröz-Tuğa, B. (2013). The role of computer-assisted language learning (CALL) in promoting learner autonomy. [Bilgisayar destekli dil öğreniminin öğrenci özerkliğini arttirmadaki rolü] Egitim Arastirmalari Eurasian Journal of Educational Research, (51), 107-122.

Navarro, D., \& Thornton, K. (2011). Investigating the relationship between belief and action in self-directed language learning. System, 39(3), 290-301. https://doi.org/10.1016/j.system.2011.07.002

Nguyen, L. T. C., \& Gu, Y. (2013). Strategy-based instruction: A learner-focused approach to developing learner autonomy. Language Teaching Research, 17(1), 9-30. https://doi.org/10.1177/1362168812457528

Nicholson, D. T. (2011). Embedding research in a field-based module through peer review and assessment for learning. Journal of Geography in Higher Education, 35(4), 529-549. https://doi.org/10.1080/03098265.2011.5 52104

Nielson, K. B. (2011). Self-study with language learning software in the workplace: What happens? Language Learning and Technology, 15(3), 110-129. http://dx.doi.org/10125/44265

Park, I. (2012). Seeking advice: Epistemic asymmetry and learner autonomy in writing conferences. Journal of Pragmatics, 44(14), 2004-2021. https://doi.org/10.1016/j.pragma.2012.09.012

Pellet, S.H.(2012). Wikis for building content knowledge in the foreign language classroom. CALICO Journal, 29(2), 224-248. https://doi.org/10.11139/cj.29.2.224-248

Phan, T. T. H., \& Hamid, M. O. (2017). Learner autonomy in foreign language policies in Vietnamese universities: An exploration of teacher agency from a sociocultural perspective. Current Issues in Language Planning, 18(1), 39-56. https://doi.org/10.1080/14664208.2016.1201231

Reinders, H., \& White, C. (2016). 20 years of autonomy and technology: How far have we come and where to next? Language Learning and Technology, 20(2), 143-154. http://dx.doi.org/10125/44466

Richards, J.C.(2015). The changing face of language learning: Learning beyond the classroom. RELC Journal, 46(1), 5-22. https://doi.org/10.1177/0033688214561621

Rivers, D. J. (2011). Strategies and struggles in the ELT classroom: Language policy, learner autonomy, and innovative practice. Language Awareness, 20(1), 31-43. https://doi.org/10.1080/09658416.2010.537343

Smith, K., \& Craig, H. (2013). Enhancing the autonomous use of CALL: A new curriculum model in EFL. CALICO Journal, 30(2), 252-278. https://doi.org/10.11139/cj.30.2.252-278

Steel, C. H., \& Levy, M. (2013). Language students and their technologies: Charting the evolution 20062011. ReCALL, 25(3), 306-320. doi:10.1017/S0958344013000128

Terhune, N. M. (2016). Language learning going global: Linking teachers and learners via commercial skypebased CMC. Computer Assisted Language Learning, 29(6), 1071-1089. https://doi.org/10.1080/09588221.2015 .1061020

Tilfarlioglu, F. Y., \& Ciftci, F. S. (2011). Supporting self-efficacy and learner autonomy in relation to academic success in EFL classrooms (A case study). Theory and Practice in Language Studies, 1(10), 1284-1294. https:// doi.org/10.4304/tpls.1.10.1284-1294

Tok, H. (2011). Classroom instructional responsibilities and learner autonomy: A case study in Turkey. Energy Education Science and Technology Part B: Social and Educational Studies, 3(3), 211-220.

Tsou, W., \& Chen, F. (2014). ESP program evaluation framework: Description and application to a Taiwanese university ESP program. English for Specific Purposes, 33(1), 39-53. https://doi.org/10.1016/j.esp.2013.07.008

Ueki, M., \& Takeuchi, O. (2013). Forming a clearer image of the ideal L2 self: The L2 motivational self system and learner autonomy in a Japanese EFL context. Innovation in Language Learning and Teaching, 7(3), 238252. doi:https://doi.org/10.1080/17501229.2013.836205

Vlachopoulos, D., \& Makri, A. (2019). Online communication and interaction in distance higher education: A framework study of good practice. International Review of Education, 65(4), 605-632. https://doi.org/10.1007/ 
s11159-019-09792-3

Wang, P. (2011). Constructivism and learner autonomy in foreign language teaching and learning: To what extent does theory inform practice? Theory and Practice in Language Studies, 1(3), 273-277. https://doi.org/10.4304/ tpls.1.3.273-277

Wang, Y., \& Qi, G. Y. (2018). Mastery-based language learning outside class: Learning support in flipped classrooms. Language Learning and Technology, 22(2), 50-74. https://doi.org/10.125/44641

Wang, Y. Shang, H., \& Briody, P. (2013). Exploring the impact of using automated writing evaluation in English as a foreign language university students' writing. Computer Assisted Language Learning, 26(3), 234-257. https://doi.org/10.1080/09588221.2012.655300

Yasmin, M., \& Sohail, A. (2018). Socio-cultural barriers in promoting learner autonomy in Pakistani universities: English teachers' beliefs. Cogent Education, 5(1), 1-12. https://doi.org/10.1080/2331186X.2018.1501888 